\title{
Cerebral perfusion and oxygenation after the Norwood procedure: Comparison of right ventricle-pulmonary artery conduit with modified Blalock-Taussig shunt
}

Barry D. Kussman, MBBCh, ${ }^{\text {a }}$ Kimberlee Gauvreau, ScD, ${ }^{\mathrm{b}}$ James A. DiNardo, MD, ${ }^{\text {a }}$ Jane W. Newburger, MD, MPH, Andrew S. Mackie, MD, SM, ${ }^{b, *}$ Karen L. Booth, MD, ${ }^{\text {, }}{ }^{\dagger}$ Pedro J. del Nido, MD, PhD, ${ }^{c}$ Stephen J. Roth, MD, MPH, ${ }^{b, t}$ and Peter C. Laussen, MBBS ${ }^{a, b}$

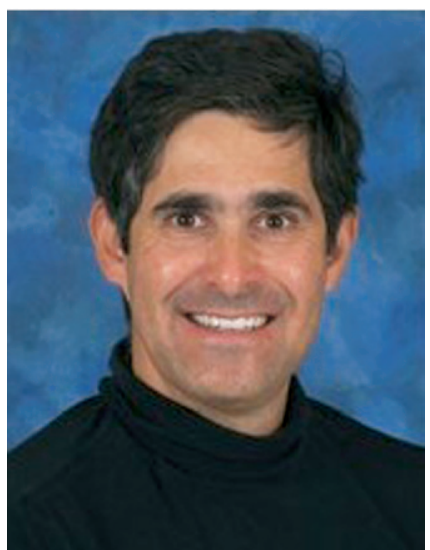

Dr Kussman
Objective: The proposed physiologic advantage of the modified Norwood procedure using a right ventricle-pulmonary artery conduit to supply pulmonary blood flow, compared with a modified Blalock-Taussig shunt, is reduced runoff from the systemic-to-pulmonary circulation during diastole, resulting in a higher diastolic blood pressure and improved systemic perfusion. We hypothesized that the modified Norwood procedure is associated with improved cerebral perfusion and oxygenation.

Methods: Transcranial Doppler sonography and near-infrared spectroscopy were performed in neonates undergoing the Norwood procedure with either a modified Blalock-Taussig shunt $(\mathrm{n}=14)$ or right ventricle-pulmonary artery conduit $(\mathrm{n}=13)$.

Results: Diastolic blood pressure was significantly higher in the right ventriclepulmonary artery group at 6 hours after bypass ( $46 \pm 7$ vs $40 \pm 4 \mathrm{~mm} \mathrm{Hg} ; P=.03$ ), on postoperative day $1(45 \pm 6$ vs $37 \pm 5 \mathrm{~mm} \mathrm{Hg} ; P=.002)$, and on postoperative day 2 (46 \pm 7 vs $37 \pm 4 \mathrm{~mm} \mathrm{Hg} ; P=.001$ ). Cerebral diastolic blood flow velocity did not differ significantly between groups at any time point or over time, but cerebral systolic blood flow velocity was higher over time in the Blalock-Taussig group $(P=.01)$. No significant differences in regional cerebral oxygen saturation were found between groups at baseline or after bypass. Blood flow velocities and cerebral oxygen saturation did not differ significantly according to use of regional low-flow perfusion.

Conclusions: The higher diastolic blood pressure after the modified Norwood procedure is not associated with higher cerebral blood flow velocities or regional cerebral oxygen saturation. This may imply an equal vulnerability to the cerebral injury associated with hemodynamic instability in the early postoperative period.

From the Departments of Anesthesiology, Perioperative and Pain Medicine, ${ }^{\mathrm{a}}$ Cardiology, ${ }^{\mathrm{b}}$ and Cardiac Surgery, ${ }^{\mathrm{c}}$ Children's Hospital Boston, and the Departments of Anaesthesia, ${ }^{\mathrm{a}}$ Pediatrics, ${ }^{\mathrm{b}}$ and Surgery, Harvard Medical School, Boston, Mass.

Supported by the Department of Anesthesiology, Perioperative and Pain Medicine Funds, the Glaser Pediatric Research Network, and grant RRO02172 from the National Institutes of Health.

Received for publication July 7, 2006; revisions received Aug 25, 2006; accepted for publication Sept 12 2006

Address for reprints: Barry D. Kussman, MBBCh, Department of Anesthesiology, Perioperative and Pain Medicine, Children's Hospital Boston, 300 Longwood Ave, Boston, MA 02115 (E-mail: barry.kussman@ childrens.harvard.edu).

*Current address: Division of Cardiology, The Montreal Children's Hospital, 2300 Tupper St, Montreal, QC, Canada H3H 1P3.

†Current address: Division of Pediatric Cardiology, Lucile Packard Children's Hospital, 750 Welch Rd, Suite 325, Palo Alto, CA 94304.

J Thorac Cardiovasc Surg 2007;133:648-55

$0022-5223 / \$ 32.00$

Copyright (C) 2007 by The American Association for Thoracic Surgery

doi:10.1016/j.jtcvs.2006.09.034 
$\mathrm{T}$ he Norwood procedure and its modifications are widely used as initial palliation for thypoplastic left heart syndrome (HLHS) or other single ventricle variants requiring aortic arch reconstruction. ${ }^{1}$ Although outcomes have improved, postoperative hemodynamic instability with low systemic oxygen delivery in the early postoperative period is a significant contributing factor to early mortality. ${ }^{2,3}$ After the Norwood procedure with pulmonary blood flow via a modified Blalock-Taussig shunt (MBTS), hemodynamic instability has been attributed in part to excessive pulmonary blood flow across the shunt and significant diastolic runoff from the coronary circulation. ${ }^{4}$ Over recent years, a modification to the Norwood procedure has been advocated that uses a right ventricle-pulmonary artery (RV-PA) conduit instead of an MBTS to re-establish pulmonary blood supply. ${ }^{5}$ The use of an RV-PA conduit has been reported by several congenital heart centers to improve early mortality. This improvement has been explained by reduced blood flow to the pulmonary circulation during diastole and a higher diastolic blood pressure, thereby resulting in better coronary and end-organ perfusion. ${ }^{6}$

A number of studies have demonstrated that preschool and school-aged children with HLHS and other single ventricle lesions who have undergone the Norwood procedure have deficits on neurocognitive testing and behavioral abnormalities. ${ }^{7}$ Although factors affecting neurodevelopmental outcome in HLHS are multifactorial, critically low cerebral oxygenation occurs commonly in the early postoperative period after the Norwood operation. ${ }^{8}$ Low diastolic blood pressure in the early postoperative period may be an important risk factor for periventricular leukomalacia. ${ }^{9}$ It is unknown whether the higher diastolic blood pressure associated with the modified Norwood procedure using an RV-PA shunt improves cerebral hemodynamics and oxygenation in the early postoperative period. The aim of this study was to compare cerebral hemodynamics and oxygenation between neonates undergoing the Norwood procedure with an MBTS with those undergoing a modified Norwood procedure with an RV-PA conduit. We hypothesized that the higher diastolic blood pressure after the RV-PA conduit results in higher cerebral blood flow velocity (CBFV) and improved cerebral oxygenation.

\section{Materials and Methods \\ Patients}

After written parental informed consent, neurologic monitoring was performed in neonates undergoing the Norwood procedure who had been enrolled in a study at Children's Hospital Boston to evaluate the effect of triiodothyronine in neonatal heart surgery. ${ }^{10}$ Patients with (1) HLHS or another functional single ventricle lesion with aortic arch obstruction or (2) interrupted aortic arch and ventricular septal defect were prospectively randomized to evaluate the effect of a continuous infusion of triiodothyronine $\left(0.05 \mu \mathrm{g} \cdot \mathrm{kg}^{-1} \cdot \mathrm{h}^{-1}\right)$ or placebo for 72 hours after cardiopulmo-

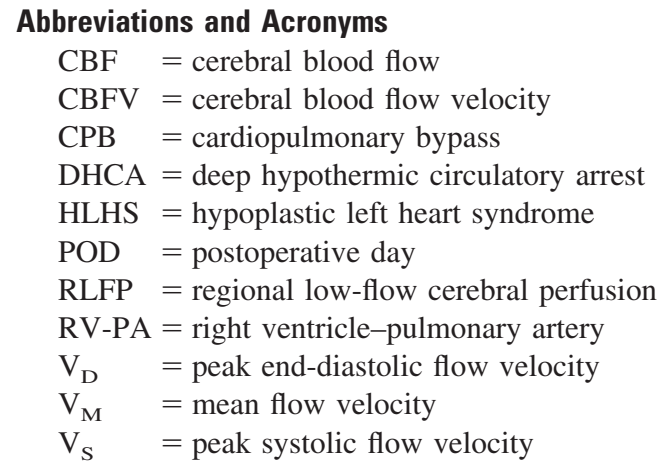

nary bypass (CPB). Patients were excluded if they had a birth weight less than $2.3 \mathrm{~kg}$, preoperative tachyarrhythmia, clinical sepsis confirmed by culture, serum creatinine greater than 133 $\mu \mathrm{mo} 1 / \mathrm{L}(1.5 \mathrm{mg} / \mathrm{dL})$ within 24 hours of surgery, or a known thyroid or metabolic disorder. This secondary study was performed to evaluate only those patients with HLHS or other functional single ventricle lesion with aortic arch obstruction with the specific aim of comparing transcranial Doppler (TCD) blood flow velocity and cerebral tissue oxygen saturation between patients having the Norwood procedure with an MBTS versus an RV-PA conduit. Patient selection for this substudy was determined solely by the schedule of the investigators and was not influenced by patient characteristics. Randomization for the primary study was not affected, and no separate selection criteria were used in that surgeon and/or cardiologist preference determined the choice of MBTS or RV-PA conduit.

\section{Clinical Techniques}

Patients underwent the Norwood procedure either with an MBTS (3.0 or $3.5 \mathrm{~mm})$ (NW-BT) or RV-PA conduit $(5.0 \mathrm{~mm})(\mathrm{NW}$ RVPA) with polytetrafluoroethylene (Gore-Tex; W. L. Gore \& Associates, Inc, Flagstaff, Ariz). A pH-stat perfusion strategy was used in all patients. Methylprednisolone $(30 \mathrm{mg} / \mathrm{kg})$ and phentolamine $(0.2 \mathrm{mg} / \mathrm{kg})$ were administered at the initiation of CPB and phentolamine $(0.2 \mathrm{mg} / \mathrm{kg})$ at the onset of rewarming. Standard pump flow rates of 150 to $200 \mathrm{~mL} \cdot \mathrm{kg}^{-1} \cdot \mathrm{min}^{-1}$ for full flow and $50 \mathrm{~mL} \cdot \mathrm{kg}^{-1} \cdot \mathrm{min}^{-1}$ for low flow were used. When the rectal temperature reached $18^{\circ} \mathrm{C}$ or lower and after at least 20 minutes of cooling, deep hypothermic circulatory arrest (DHCA) was begun. At the discretion of the attending surgeon, regional lowflow cerebral perfusion (RLFP) with pump flows of 20 to 40 $\mathrm{mL} \cdot \mathrm{kg}^{-1} \cdot \min ^{-1}$ was performed at deep hypothermia during neoaortic and arch reconstruction through a polytetrafluoroethylene shunt anastomosed to the innominate artery. Continuous ultrafiltration was performed during rewarming.

Anesthetic technique was not specifically controlled but was conducted according to our institutional practice. High-dose opioid anesthesia (fentanyl $100 \mu \mathrm{g} / \mathrm{kg}$ ) was supplemented with midazolam and/or isoflurane as tolerated, and neuromuscular blockade was achieved with pancuronium. The head was turned to just off the midline to prevent pressure or movement on the endotracheal tube by the surgical team while avoiding the possible effects of 
extremes of lateral head position on cerebral blood flow (CBF) and venous drainage.

\section{Monitoring and Data Acquisition}

A 2-Mz, range-gated, pulsed-wave TCD sonographic probe (MultiDop T; DWL Elektronische Systeme GmbH, Sipplingen, Germany) was placed over the right temporal window to measure middle cerebral artery blood flow velocity in the proximal (M1) segment of the middle cerebral artery. To ensure a reproducible window, the signal from the artery was adjusted to be accompanied by retrograde anterior cerebral artery flow (A1 segment). After an acceptable waveform had been achieved, the probe position was secured. Meticulous care was taken to ensure a constant position, insonation depth, sample volume, gain, and power of ultrasound for all measurements. Peak systolic flow velocity $\left(\mathrm{V}_{\mathrm{S}}\right)$, mean flow velocity $\left(\mathrm{V}_{\mathrm{M}}\right)$, and peak end-diastolic flow velocity $\left(\mathrm{V}_{\mathrm{D}}\right)$ were measured during hemodynamically stable intervals, with constant recordings of at least 15 seconds' duration. Middle cerebral arterial resistance index $(\mathrm{RI})$ was calculated according to the formula $\mathrm{RI}=$ $\left(\mathrm{V}_{\mathrm{S}}-\mathrm{V}_{\mathrm{D}}\right) / \mathrm{V}_{\mathrm{S}} \cdot{ }^{11}$

Bihemispheric cerebral tissue oxygen saturation was measured by near-infrared spectroscopy with the INVOS 5100 (Somanetics, Troy, Mich). After the induction of anesthesia, Pediatric SomaSensors (Somanetics) were placed on the right and left sides of the forehead according to the manufacturer's guidelines. After an accommodation period, data collection was begun and downloaded to storage disk every 10 seconds throughout the case for further analysis. The scale unit for the regional saturation of oxygen $\left(\mathrm{rSO}_{2}\right)$ is percent. $\mathrm{As} \mathrm{rSo}_{2}$ is close to mixed venous oxygen saturation, ${ }^{12}$ cerebral extraction of oxygen $\left(\mathrm{CEO}_{2}\right)$ can be estimated from the difference of arterial oxygen saturation $\left(\mathrm{SaO}_{2}\right)$ and $\mathrm{rSO}_{2}\left(\mathrm{CEO}_{2}=\mathrm{SaO}_{2}-\mathrm{rSO}_{2}\right) \cdot{ }^{13}$

Intraoperative and postoperative data were collected and analyzed at the following time points: after induction, initiation of CPB, 10 minutes after start of cooling, onset of low-flow CPB, onset of DHCA, resumption of low-flow CPB, start of rewarming, 10 minutes after start of rewarming, warm flow $\left(35^{\circ} \mathrm{C}\right)$, immediately off $\mathrm{CPB}, 60$ minutes after $\mathrm{CPB}, 6$ hours after $\mathrm{CPB}$, and postoperative day (POD) 1 and POD 2. Cardiac index, oxygen delivery, oxygen consumption, and inotrope score were determined postoperatively as previously described. ${ }^{10}$

\section{Statistical Analysis}

Patient characteristics, clinical data, laboratory data, TCD velocities, and cerebral oxygen saturation data were compared for patients in the NW-BT and NW-RVPA groups. Most continuous variables were approximately normally distributed and were summarized as the mean \pm standard deviation; comparisons between groups were performed with the 2 -sample $t$ test. Continuous variables that were not normally distributed were summarized as the median (range) and compared with the Wilcoxon rank sum test. Categorical variables were compared by the Fisher exact test. Additional comparisons of TCD velocities controlling for hematocrit level were performed by linear regression analysis. Differences in the trends of serial measurements of TCD velocities, resistance indices, and cerebral $\mathrm{rSO}_{2}$ over time were assessed by 2-way analysis of variance with repeated measures on one factor. These variables were also compared for patients with and without
TABLE 1. Patient characteristics

\begin{tabular}{|c|c|c|c|}
\hline Characteristic & $\begin{array}{l}\text { NW-BT } \\
(n=14)\end{array}$ & $\begin{array}{c}\text { NW-RVPA } \\
(n=13)\end{array}$ & $P$ value \\
\hline Age at operation (d) & $5(3-15)$ & $7(3-11)$ & .41 \\
\hline Birth weight $(\mathrm{kg})$ & $3.20 \pm 0.55$ & $3.48 \pm 0.60$ & .22 \\
\hline $\begin{array}{l}\text { Gestational age at birth } \\
\text { (wk) }\end{array}$ & $38.9 \pm 1.9$ & $38.9 \pm 1.8$ & .76 \\
\hline Male gender $(\%)$ & $6(42.9 \%)$ & $9(69.2 \%)$ & .25 \\
\hline \multicolumn{4}{|l|}{ Diagnosis, n (\%) } \\
\hline HLHS & $12(85.7 \%)$ & $11(84.6 \%)$ & 1.0 \\
\hline $\begin{array}{l}\text { Other SV with arch } \\
\text { obstruction }\end{array}$ & $2(14.3 \%)$ & $2(15.4 \%)$ & \\
\hline Randomized to T3 (\%) & $7(50.0 \%)$ & $6(46.2 \%)$ & 1.0 \\
\hline Duration of CРB (min) & $163 \pm 31$ & $133 \pm 32$ & .023 \\
\hline $\begin{array}{l}\text { Duration of aortic } \\
\text { crossclamping (min) }\end{array}$ & $58 \pm 17$ & $53 \pm 30$ & .62 \\
\hline Duration of DHCA (min) & $36 \pm 19$ & $51 \pm 18$ & .040 \\
\hline
\end{tabular}

Data are presented as mean $\pm S D$ or median (range). NW-BT, Norwood with modified Blalock-Taussig shunt; NW-RVPA, Norwood with right ventriclepulmonary artery conduit; $H L H S$, hypoplastic left heart syndrome; $S V$, single ventricle; $T 3$, triiodothyronine; $C P B$, cardiopulmonary bypass; $D H C A_{\text {, }}$ deep hypothermic circulatory arrest. Boldface $P$ values indicate significance.

RLFP within the NW-BT subgroup only by the 2-sample $t$ test. Because all analyses were considered exploratory, no adjustments were made for multiple comparisons.

\section{Results}

Among 38 neonates undergoing a Norwood procedure during the study period, 27 (71\%) underwent TCD sonography and cerebral oxygenation monitoring. These patients comprise the cohort for the present study.

Fourteen patients had NW-BT and 13 had NW-RVPA. Demographic data and CPB variables are presented in Table 1. There were no significant differences between the groups with respect to demographic variables, diagnosis, or randomization to triiodothyronine. A similar number of patients in the NW-BT and NW-RVPA groups received triiodothyronine, and no differences in Doppler measurements or cerebral oxygenation were found between those neonates who received triiodothyronine versus those who did not. The NW-BT group had a significantly longer duration of CPB and shorter duration of DHCA. This was coupled with the use of RLFP in 10 patients, 9 in the NW-BT group and 1 in the NW-RVPA group $(P=.004)$. The nadir tympanic temperature on $\mathrm{CPB}$ was $16.9^{\circ} \mathrm{C} \pm 1.5^{\circ} \mathrm{C}$ in the $\mathrm{NW}-\mathrm{BT}$ group and $18.9^{\circ} \mathrm{C} \pm 4.0^{\circ} \mathrm{C}$ in the NW-RVPA group $(P=$ .19); no differences in temperature were found between the groups at any time point.

TCD data are presented in Table 2. The $\mathrm{V}_{\mathrm{D}}$ was similar in both groups overall, and at each individual time point. The NW-BT group had significantly higher $\mathrm{V}_{\mathrm{S}}$ overall $(P=.01)$; in particular, it was higher at 60 minutes after $\mathrm{CPB}$ and on POD 1. There were no differences in cerebral $V_{M}$ between 
TABLE 2. TCD data

\begin{tabular}{|c|c|c|c|}
\hline Variable & $\begin{array}{l}\text { NW-BT } \\
(n=14)\end{array}$ & $\begin{array}{c}\text { NW-RVPA } \\
(n=13)\end{array}$ & $P$ value \\
\hline \multicolumn{4}{|l|}{$V_{S}(\mathrm{~cm} / \mathrm{s})$} \\
\hline Postinduction & $53 \pm 12$ & $60 \pm 18$ & .26 \\
\hline Off CPB & $48 \pm 19$ & $41 \pm 16$ & .34 \\
\hline 60 min after CPB & $54 \pm 14$ & $41 \pm 10$ & .01 \\
\hline $6 \mathrm{~h}$ after CPB & $54 \pm 25$ & $45 \pm 13$ & .37 \\
\hline POD 1 (24 h) & $65 \pm 17$ & $52 \pm 14$ & .05 \\
\hline POD 2 (48 h) & $71 \pm 23$ & $63 \pm 12$ & .27 \\
\hline \multicolumn{4}{|l|}{$V_{D}(\mathrm{~cm} / \mathrm{s})$} \\
\hline Postinduction & $9 \pm 9$ & $10 \pm 11$ & .69 \\
\hline Off CPB & $4 \pm 5$ & $1 \pm 2$ & .06 \\
\hline 60 min after $\mathrm{CPB}$ & $5 \pm 5$ & $2 \pm 3$ & .09 \\
\hline $6 \mathrm{~h}$ after CPB & $4 \pm 4$ & $5 \pm 6$ & .67 \\
\hline POD 1 (24 h) & $9 \pm 8$ & $11 \pm 7$ & .55 \\
\hline POD 2 (48 h) & $10 \pm 7$ & $11 \pm 7$ & .67 \\
\hline \multicolumn{4}{|l|}{$V_{M}(\mathrm{~cm} / \mathrm{s})$} \\
\hline Postinduction & $25 \pm 10$ & $26 \pm 11$ & .72 \\
\hline Off CPB & $21 \pm 10$ & $15 \pm 11$ & .19 \\
\hline 60 min after CPB & $23 \pm 7$ & $14 \pm 5$ & .001 \\
\hline $6 \mathrm{~h}$ after CPB & $21 \pm 10$ & $17 \pm 6$ & .33 \\
\hline POD 1 (24 h) & $29 \pm 10$ & $23 \pm 9$ & .12 \\
\hline POD 2 (48 h) & $32 \pm 10$ & $28 \pm 8$ & .23 \\
\hline \multicolumn{4}{|l|}{ RI } \\
\hline Postinduction & $0.85 \pm 0.15$ & $0.85 \pm 0.15$ & .97 \\
\hline Off CPB & $0.90 \pm 0.12$ & $0.98 \pm 0.04$ & .04 \\
\hline 60 min after CPB & $0.91 \pm 0.09$ & $0.95 \pm 0.08$ & .19 \\
\hline $6 \mathrm{~h}$ after $\mathrm{CPB}$ & $0.94 \pm 0.06$ & $0.89 \pm 0.12$ & .42 \\
\hline POD 1 (24 h) & $0.87 \pm 0.11$ & $0.81 \pm 0.10$ & .14 \\
\hline POD 2 (48 h) & $0.86 \pm 0.08$ & $0.82 \pm 0.10$ & .21 \\
\hline
\end{tabular}

Data are presented as mean \pm SD. TCD, Transcranial Doppler; $N W-B T$, Norwood with modified Blalock-Taussig shunt; NW-RVPA, Norwood with right ventricle-pulmonary artery conduit; $V_{S}$, peak systolic flow velocity; $V_{D}$, peak end-diastolic flow velocity; $V_{M}$, mean flow velocity; $R I$, resistance index; $C P B$, cardiopulmonary bypass; $P O D$, postoperative day. Boldface $P$ values indicate significance.

the groups apart from a higher value in the NW-BT group at 60 minutes after $\mathrm{CPB}$. The resistance index immediately off $\mathrm{CPB}$ was lower in the NW-BT group, but there were no differences between groups at the other time points.

Within-group comparison of mean left and right $\mathrm{rSO}_{2}$ and $\mathrm{CEO}_{2}$ at each time point found no differences between the left and right sides. Mean $\mathrm{rSO}_{2}$ and $\mathrm{CEO}_{2}$ values for the right side (same side as TCD sonography) are presented in Table 3. There were no significant differences between the groups with respect to $\mathrm{rSO}_{2}$ or $\mathrm{CEO}_{2}$ at any time point except for a higher $\mathrm{rSO}_{2}$ in the NW-BT group at the end of DHCA $(75 \% \pm 19 \%$ vs $58 \% \pm 9 \% ; P=.01)$. According to repeated-measures analysis of variance, changes in $\mathrm{rSO}_{2}$ and $\mathrm{CEO}_{2}$ over time were similar in the NW-BT and NW-RVPA groups. Comparing the 9 NW-BT patients who had RLFP to the 5 without, we found no statistically significant differ- ences in middle cerebral artery velocities, resistance indices, and $\mathrm{rSO}_{2}$ measurements.

Comparison of those patients who had RLFP $(n=10)$ with those who had DHCA $(\mathrm{n}=17)$ found no differences in CBFVs $\left(\mathrm{V}_{\mathrm{S}}, \mathrm{V}_{\mathrm{D}}\right.$, or $\left.\mathrm{V}_{\mathrm{M}}\right)$ at any time point. The mean $\mathrm{rSo}_{2}$ was higher at the end of RLFP than at the end of DHCA $(79 \% \pm 17 \%$ vs $62 \% \pm 14 \% ; P=.02)$, but there were no differences in $\mathrm{rSO}_{2}$ at any other time point and $\mathrm{CEO}_{2}$ was the same for both groups at all time points. The $\mathrm{rSO}_{2}$ values for each group (data not presented) were similar to those shown for the NW-BT and NW-RVPA groups in Table 3.

Clinical and laboratory data are presented in Tables 4 and 5 , respectively.

Diastolic blood pressure was significantly higher in the NW-RVPA group at 6 hours after CPB ( $46 \pm 7$ vs $40 \pm 4$ $\mathrm{mm} \mathrm{Hg} ; P=.03$ ), on POD 1 (45 \pm 6 vs $37 \pm 5 \mathrm{~mm} \mathrm{Hg}$; $P=.002$ ), and on POD 2 (46 \pm 7 vs $37 \pm 4 \mathrm{~mm} \mathrm{Hg} ; P=$ .001). Systolic blood pressure was not different between groups at any time point. Mean blood pressure in the NWRVPA group tended to be higher on POD 1 and was significantly higher on POD $2(55 \pm 7$ vs $48 \pm 5 \mathrm{~mm} \mathrm{Hg}$; $P=.01$ ). Heart rates tended to be lower in the NW-RVPA group postoperatively (data not presented). Cerebral perfusion pressure (mean blood pressure minus central venous pressure or right atrial pressure) was higher in the NWRVPA group on POD $2(46 \pm 8$ vs $40 \pm 5 \mathrm{~mm} \mathrm{Hg} ; P=.03$ ) but was similar at the other time points. There were no significant differences between groups with respect to hematocrit apart from a higher hematocrit on POD 2 in the NW-RVPA group $(45.8 \% \pm 5.3 \%$ vs $41.0 \% \pm 4.6 \% ; P=$ .02). The groups did not differ in $\mathrm{V}_{\mathrm{D}}$ even after adjusting for hematocrit level. The arterial partial pressures of carbon dioxide $\left(\mathrm{PaCO}_{2}\right)$ and arterial $\mathrm{pH}$ were similar at all time points. Arterial oxygen tension $\left(\mathrm{PaO}_{2}\right)$ was significantly lower in the NW-RVPA group at 6 hours after CPB (35 \pm 5 vs $43 \pm 7 \mathrm{~mm} \mathrm{Hg} ; P=.04)$, on POD 1 ( $37 \pm 3$ vs $43 \pm$ $6 \mathrm{~mm} \mathrm{Hg} ; P=.002)$, and POD $2(36 \pm 5$ vs $42 \pm 3 \mathrm{~mm}$ $\mathrm{Hg} ; P=.002)$ despite use of higher fractional inspired oxygen concentrations $\left(\mathrm{FIO}_{2} ; P=.001\right)$. The $\mathrm{PaO}_{2} / \mathrm{FIO}_{2}$ ratios were thus lower for the NW-RVPA group at these time points.

Indirect indices of cardiac output, namely arterial lactate and mixed venous oxygen saturation, did not differ between groups at any time point (Table 5).

Cardiac index was only measured in 12 NW-BT patients and 6 NW-RVPA patients $(P=0.79)$ because of lack of or inadequate position of a central venous line or unreliable oxygen consumption data $\left(\mathrm{FIO}_{2}>0.4\right)$. Mean cardiac index, oxygen delivery, oxygen consumption, and oxygen delivery/oxygen consumption ratio were the same in both groups at 48 hours postoperatively (Table 6). The NW-BT group had a higher inotrope score on POD 2 and a higher cumulative 5-day inotrope score $(78.5 \pm 22.0$ vs $47.3 \pm$ 
TABLE 3. Cerebral oxygenation data

\begin{tabular}{|c|c|c|c|c|c|c|}
\hline & \multicolumn{3}{|c|}{ Right $\mathrm{rSO}_{2}(\%)$} & \multicolumn{3}{|c|}{ Right $\mathrm{CE}_{2}(\%)$} \\
\hline & $N W-B T(n=14)$ & NW-RVPA $(n=13)$ & $P$ value & $N W-B T(n=14)$ & NW-RVPA $(n=13)$ & $P$ value \\
\hline Postinduction & $61 \pm 15$ & $60 \pm 6$ & .91 & $33 \pm 16$ & $34 \pm 6$ & .85 \\
\hline On CPB & $71 \pm 17$ & $73 \pm 8$ & .79 & $29 \pm 15$ & $26 \pm 10$ & .71 \\
\hline 10 min after cooling & $92 \pm 7$ & $93 \pm 4$ & .59 & $9 \pm 8$ & $7 \pm 5$ & .59 \\
\hline Onset DHCA & $92 \pm 6$ & $94 \pm 3$ & .55 & $7 \pm 4$ & $6 \pm 1$ & .59 \\
\hline Resume CPB & $75 \pm 19$ & $58 \pm 9$ & .01 & $26 \pm 23$ & 45 & - \\
\hline Warm flow & $80 \pm 11$ & $82 \pm 10$ & .55 & $20 \pm 12$ & $18 \pm 10$ & .63 \\
\hline Off CPB & $61 \pm 14$ & $62 \pm 14$ & .92 & $21 \pm 9$ & $22 \pm 12$ & .80 \\
\hline 60 min after CPB & $54 \pm 12$ & $52 \pm 11$ & .65 & $30 \pm 13$ & $25 \pm 12$ & .31 \\
\hline $6 \mathrm{~h}$ after $\mathrm{CPB}$ & $45 \pm 11$ & $51 \pm 8$ & .20 & $35 \pm 10$ & $26 \pm 9$ & .09 \\
\hline POD 1 (24 h) & $57 \pm 10$ & $54 \pm 7$ & .47 & $25 \pm 9$ & $22 \pm 10$ & .36 \\
\hline POD 2 (48 h) & $57 \pm 8$ & $52 \pm 8$ & .18 & $22 \pm 10$ & $25 \pm 7$ & .41 \\
\hline
\end{tabular}

Data are presented as mean $\pm \mathrm{SD}$. $r \mathrm{SO}_{2}$, Regional saturation of oxygen; $C \mathrm{CO}_{2}$, cerebral extraction of oxygen; $N W$ - $B T$, Norwood with modified BlalockTaussig shunt; NW-RVPA, Norwood with right ventricle-pulmonary artery conduit; CPB, cardiopulmonary bypass; $D H C A$, deep hypothermic circulatory arrest; $P O D$, postoperative day. Boldface $P$ values indicate significance.

$29.9 ; P=.005$ ). Coronary perfusion pressure (calculated as mean diastolic blood pressure minus atrial pressure) was higher in the NW-RVPA group on POD 1 ( $36 \pm 7$ vs $29 \pm$ $4 ; P=.02)$ and POD $2(35 \pm 4$ vs $27 \pm 6 ; P=.004)$, with a trend to a higher score at 6 hours after CPB. Serum creatinine was lower in the NW-RVPA group on POD 1 $(0.64 \pm 0.18$ vs $0.81 \pm 0.21 ; P=.04)$ and POD $2(0.59 \pm$ 0.23 vs $0.79 \pm 0.17 ; P=.02$ ), with a trend to lower blood urea nitrogen postoperatively. Urine output in the first 24 hours was lower in the NW-RVPA group $(393 \pm 150$ vs $269 \pm 117 ; P=0.02$ ), but not subsequently. There were no differences between the groups with respect to recovery after surgery. There were no in-hospital deaths, and the incidence of serious adverse events, including cardiac arrest, seizures, and infectious complications, did not differ between the groups.

\section{Discussion}

The principal finding of this study is that the modified Norwood procedure with RV-PA conduit, compared with the Norwood with MBTS, is not associated with higher CBFVs or with improved regional cerebral oxygen saturation despite the higher postoperative diastolic blood pressures. As compared with neonates who undergo the Norwood procedure with an MBTS, our results may imply an equal vulnerability to the cerebral injury associated with hemodynamic instability and decreased oxygen delivery in the early postoperative period.

TCD has been used in pediatric cardiac surgery to assess CBF. ${ }^{14}$ Although TCD has been found to correlate well with CBF estimated by xenon 133 clearance, thermodilution, and microsphere techniques, ${ }^{14-16}$ it is best used to observe changes rather than to quantitate specific regional flow in a particular area. The Fick (Kety-Schmidt) and xenon 133 clearance methods are the gold standard techniques for measuring CBF, but they are invasive, cumbersome, expensive, and not practical for routine clinical use. TCD is a noninvasive means to estimate cerebral volume flow in the larger conduction vessels at the base of the brain, ${ }^{17}$ and it is reproducible, ${ }^{18}$ inexpensive, portable, and widely available. Blood flow through a vessel is equal to the instantaneous average velocity times the cross-sectional area of the vessel and is based on the assumption that the cross-sectional area and the flow profile of the cerebral vessel remain constant during the period of investigation. ${ }^{19}$ In clinical practice, because the actual vessel diameter and perfusion territory of the interrogated cerebral artery are not known, only inferences can be made regarding blood flow from velocity measurements.

In our study, a higher diastolic blood pressure was found in the NW-RVPA group from 6 hours after CPB, but without a corresponding increase in diastolic and mean CBFVs. Decreased CBF after DHCA has been found in the period during rewarming and after bypass and can persist into the early postoperative period. ${ }^{20,21}$ Diastolic CBFV has been shown to normalize 54 to 328 minutes after DHCA. ${ }^{22}$ Although very low diastolic velocities may limit the ability to detect differences between the groups (technical considerations), ${ }^{11}$ any significant difference should be detectable at the higher baseline (postinduction) velocities seen on the first POD. The same diastolic velocities, as well as the return to baseline values, found between the NW-BT and NW-RVPA groups postoperatively, are highly suggestive of recovery of cerebrovascular autoregulation by POD 1 . Recent evidence suggests that cerebrovascular pressure autoregulation is disturbed at 6 hours after surgery in only 13\% of infants who have undergone greater than 20 minutes of DHCA. ${ }^{23}$ The similar mean velocities between the groups 
TABLE 4. Clinical data

\begin{tabular}{|c|c|c|c|}
\hline Variable & $\begin{array}{l}\text { NW-BT } \\
(n=14)\end{array}$ & $\begin{array}{c}\text { NW-RVPA } \\
(n=13)\end{array}$ & $P$ value \\
\hline \multicolumn{4}{|c|}{ Systemic blood pressure $(\mathrm{mm} \mathrm{Hg})$} \\
\hline Postinduction & $68 \pm 9$ & $69 \pm 9$ & .82 \\
\hline Off CPB & $62 \pm 9$ & $61 \pm 8$ & .81 \\
\hline 60 min after CPB & $70 \pm 12$ & $69 \pm 11$ & .75 \\
\hline $6 \mathrm{~h}$ after $\mathrm{CPB}$ & $69 \pm 12$ & $73 \pm 10$ & .56 \\
\hline POD 1 (24 h) & $68 \pm 14$ & $70 \pm 9$ & .70 \\
\hline POD 2 (48 h) & $69 \pm 10$ & $73 \pm 8$ & .36 \\
\hline \multicolumn{4}{|c|}{ Diastolic blood pressure $(\mathrm{mm} \mathrm{Hg})$} \\
\hline Postinduction & $40 \pm 7$ & $36 \pm 8$ & .17 \\
\hline Off CPB & $34 \pm 7$ & $35 \pm 8$ & .68 \\
\hline 60 min after CPB & $39 \pm 6$ & $42 \pm 7$ & .23 \\
\hline $6 \mathrm{~h}$ after $\mathrm{CPB}$ & $40 \pm 4$ & $46 \pm 7$ & .03 \\
\hline POD 1 (24 h) & $37 \pm 5$ & $45 \pm 6$ & .002 \\
\hline POD 2 (48 h) & $37 \pm 4$ & $46 \pm 7$ & .001 \\
\hline \multicolumn{4}{|c|}{ Mean blood pressure $(\mathrm{mm} \mathrm{Hg})$} \\
\hline Postinduction & $51 \pm 6$ & $47 \pm 7$ & .13 \\
\hline Off CPB & $45 \pm 6$ & $45 \pm 7$ & .83 \\
\hline 60 min after CPB & $51 \pm 7$ & $53 \pm 6$ & .42 \\
\hline $6 \mathrm{~h}$ after $\mathrm{CPB}$ & $49 \pm 7$ & $55 \pm 8$ & .11 \\
\hline POD 1 (24 h) & $48 \pm 9$ & $53 \pm 7$ & .07 \\
\hline POD 2 (48 h) & $48 \pm 5$ & $55 \pm 7$ & .01 \\
\hline \multicolumn{4}{|c|}{$\begin{array}{l}\text { Cerebral perfusion pressure } \\
\qquad(\mathrm{mm} \mathrm{Hg})\end{array}$} \\
\hline Postinduction & $43 \pm 6$ & $41 \pm 9$ & .41 \\
\hline On CPB & $40 \pm 10$ & $37 \pm 11$ & .49 \\
\hline 10 min after cooling & $33 \pm 9$ & $30 \pm 8$ & .51 \\
\hline Onset DHCA & $20 \pm 6$ & $18 \pm 12$ & .68 \\
\hline Resume CPB & $23 \pm 10$ & $19 \pm 11$ & .58 \\
\hline Warm flow & $43 \pm 12$ & $36 \pm 8$ & .12 \\
\hline Off CPB & $36 \pm 5$ & $35 \pm 8$ & .49 \\
\hline 60 min after CPB & $40 \pm 6$ & $40 \pm 7$ & .93 \\
\hline $6 \mathrm{~h}$ after $\mathrm{CPB}$ & $41 \pm 8$ & $47 \pm 10$ & .17 \\
\hline POD 1 (24 h) & $39 \pm 8$ & $45 \pm 7$ & .10 \\
\hline POD 2 (48 h) & $40 \pm 5$ & $46 \pm 8$ & .03 \\
\hline \multicolumn{4}{|l|}{$\mathrm{SaO}_{2}(\%)$} \\
\hline Postinduction & $93 \pm 6$ & $94 \pm 5$ & .84 \\
\hline On CPB & $100 \pm 0$ & $96 \pm 7$ & .14 \\
\hline 10 min after cooling & $100 \pm 0$ & $100 \pm 0$ & - \\
\hline Off CPB & $82 \pm 14$ & $82 \pm 11$ & .94 \\
\hline 60 min after CPB & $84 \pm 7$ & $76 \pm 10$ & .03 \\
\hline $6 \mathrm{~h}$ after CPB & $79 \pm 8$ & $77 \pm 4$ & .69 \\
\hline POD 1 (24 h) & $82 \pm 3$ & $76 \pm 8$ & .02 \\
\hline POD 2 (48 h) & $79 \pm 5$ & $77 \pm 7$ & .51 \\
\hline
\end{tabular}

Data are presented as mean \pm SD. $N W$ - $B T$, Norwood with modified BlalockTaussig shunt; NW-RVPA, Norwood with right ventricle-pulmonary artery conduit; $D H C A$, deep hypothermic circulatory arrest; $P O D$, postoperative day; $C P B$, cardiopulmonary bypass; $\mathrm{SaO}_{2}$, arterial oxygen saturation. Boldface $P$ values indicate significance.

further support this, despite a higher cerebral perfusion pressure in the NW-RVPA group on POD 2. The $\mathrm{V}_{\mathrm{S}}$ and $\mathrm{V}_{\mathrm{M}}$ in the NW-BT group at 60 minutes after $\mathrm{CPB}$ were significantly higher, despite no differences between the
TABLE 5. Laboratory data

\begin{tabular}{|c|c|c|c|}
\hline Variable & $\begin{array}{c}\text { NW-BT } \\
(n=14)\end{array}$ & $\begin{array}{c}\text { NW-RVPA } \\
(\mathrm{n}=13)\end{array}$ & $P$ value \\
\hline \multicolumn{4}{|l|}{ Hematocrit (\%) } \\
\hline Postinduction & $38.9 \pm 3.8$ & $40.8 \pm 3.9$ & .21 \\
\hline 10 min after cooling & $30.5 \pm 2.7$ & $30.1 \pm 3.7$ & .74 \\
\hline Off CPB & $36.4 \pm 4.3$ & $37.1 \pm 2.9$ & .65 \\
\hline 60 min after CPB & $36.8 \pm 4.2$ & $35.9 \pm 5.5$ & .68 \\
\hline POD 1 (24 h) & $44.2 \pm 5.4$ & $47.4 \pm 4.3$ & .11 \\
\hline POD 2 (48 h) & $41.0 \pm 4.6$ & $45.8 \pm 5.3$ & .02 \\
\hline \multicolumn{4}{|l|}{$\mathrm{PaCO}_{2}(\mathrm{~mm} \mathrm{Hg})$} \\
\hline Postinduction & $43.5 \pm 6.6$ & $42.6 \pm 5.3$ & .70 \\
\hline 10 min after cooling & $46.6 \pm 7.8$ & $43.7 \pm 5.9$ & .31 \\
\hline Off CPB & $38.2 \pm 4.0$ & $37.4 \pm 5.8$ & .69 \\
\hline 60 min after CPB & $43.4 \pm 7.7$ & $40.5 \pm 6.4$ & .31 \\
\hline POD 1 (24 h) & $46.8 \pm 6.4$ & $43.8 \pm 8.6$ & .33 \\
\hline POD 2 (48 h) & $44.8 \pm 9.0$ & $48.4 \pm 7.5$ & .30 \\
\hline \multicolumn{4}{|l|}{$\mathrm{PaO}_{2}(\mathrm{~mm} \mathrm{Hg})$} \\
\hline Postinduction & $75 \pm 21$ & $80 \pm 45$ & .72 \\
\hline 10 min after cooling & $691 \pm 211$ & $653 \pm 189$ & .64 \\
\hline Off CPB & $44 \pm 10$ & $40 \pm 9$ & .36 \\
\hline 60 min after CPB & $74 \pm 102$ & $39 \pm 9$ & .22 \\
\hline $6 \mathrm{~h}$ after $\mathrm{CPB}$ & $43 \pm 7$ & $35 \pm 5$ & .04 \\
\hline POD 1 (24 h) & $43 \pm 6$ & $37 \pm 3$ & .002 \\
\hline POD 2 (48 h) & $42 \pm 3$ & $36 \pm 5$ & .002 \\
\hline \multicolumn{4}{|l|}{$\mathrm{pH}$} \\
\hline Postinduction & $7.42 \pm 0.08$ & $7.42 \pm 0.09$ & .95 \\
\hline 10 min after cooling & $7.35 \pm 0.06$ & $7.39 \pm 0.05$ & .08 \\
\hline Off CPB & $7.44 \pm 0.05$ & $7.47 \pm 0.05$ & .15 \\
\hline 60 min after CPB & $7.38 \pm 0.08$ & $7.42 \pm 0.04$ & .12 \\
\hline POD 1 (24 h) & $7.41 \pm 0.05$ & $7.46 \pm 0.08$ & .08 \\
\hline POD 2 (48 h) & $7.43 \pm 0.07$ & $7.45 \pm 0.05$ & .24 \\
\hline \multicolumn{4}{|l|}{ Lactate (mmol/L) } \\
\hline Postinduction & $2.4 \pm 1.8$ & $2.2 \pm 1.3$ & .76 \\
\hline 10 min after cooling & $3.4 \pm 1.4$ & $3.0 \pm 0.9$ & .34 \\
\hline Off CPB & $6.1 \pm 1.4$ & $7.1 \pm 3.3$ & .40 \\
\hline 60 min after CPB & $6.6 \pm 2.3$ & $7.2 \pm 2.1$ & .52 \\
\hline POD 1 (24 h) & $2.6 \pm 0.6$ & $3.4 \pm 3.9$ & .48 \\
\hline POD 2 (48 h) & $1.4 \pm 0.3$ & $1.4 \pm 0.6$ & .96 \\
\hline \multicolumn{4}{|l|}{$\mathrm{SvO}_{2}(\%)$} \\
\hline Postinduction & $64.0 \pm 17.0$ & $56.8 \pm 11.8$ & .26 \\
\hline 10 min after cooling & $99.9 \pm 0.3$ & $91.8 \pm 28.2$ & .33 \\
\hline Off CPB & $59.4 \pm 21.0$ & $69.6 \pm 20.2$ & .47 \\
\hline 60 min after CPB & $52.1 \pm 25.6$ & $54.3 \pm 14.5$ & .88 \\
\hline $6 \mathrm{~h}$ after $\mathrm{CPB}$ & $49.4 \pm 17.8$ & $43.3 \pm 23.0$ & 69 \\
\hline POD 1 (24 h) & $48.2 \pm 10.6$ & $49.8 \pm 12.2$ & .78 \\
\hline POD 2 (48 h) & $48.8 \pm 8.7$ & $48.6 \pm 13.9$ & .98 \\
\hline
\end{tabular}

Data are presented as mean \pm SD. NW-BT, Norwood with modified BlalockTaussig shunt; NW-RVPA, Norwood with right ventricle-pulmonary artery conduit; $\mathrm{PaCO}_{2}$, arterial partial pressure of carbon dioxide; $\mathrm{PaO}_{2}$, arterial oxygen tension; $\mathrm{SvO}_{2}$, mixed venous oxygen saturation; $\mathrm{CPB}$, cardiopulmonary bypass; $P O D$, postoperative day. Boldface $P$ values indicate significance.

groups in any of the measured factors known to influence CBFV. ${ }^{24}$ Although speculative and needing further study, one explanation may be the use of RLFP and the shorter duration of DHCA in the NW-BT group. 
TABLE 6. ICU data

\begin{tabular}{|c|c|c|c|}
\hline Variable & NW-BT & NW-RVPA & $P$ value \\
\hline $\begin{array}{l}\text { Cardiac index POD } 2(48 \mathrm{~h}) \\
\left(\mathrm{L} \cdot \mathrm{min}^{-1} \cdot \mathrm{m}^{-2}\right)\end{array}$ & $2.08 \pm 0.66$ & $2.18 \pm 0.78$ & .79 \\
\hline $\begin{array}{l}\mathrm{Do}_{2} \text { POD } 2(48 \mathrm{~h}) \\
\quad\left(\mathrm{mL} \cdot \mathrm{min}^{-1} \cdot \mathrm{m}^{-2}\right)\end{array}$ & $66.7 \pm 23.1$ & $69.7 \pm 24.7$ & .81 \\
\hline $\begin{array}{l}\mathrm{V}_{\mathrm{O}_{2}} \text { POD } 2(48 \mathrm{~h}) \\
\quad\left(\mathrm{mL} \cdot \min ^{-1} \cdot \mathrm{m}^{-2}\right)\end{array}$ & $21.9 \pm 5.8$ & $23.6 \pm 4.5$ & .54 \\
\hline $\begin{array}{l}\mathrm{Do}_{2} / \mathrm{No}_{2} \text { ratio } \\
\text { Inotrope score }\end{array}$ & $3.09 \pm 0.93$ & $2.92 \pm 0.71$ & .69 \\
\hline POD 1 (24 h) & $10.2 \pm 5.1$ & $11.0 \pm 5.3$ & .7 \\
\hline POD 2 (48 h) & $19.1 \pm 5.5$ & $13.9 \pm 6.6$ & .04 \\
\hline $\begin{array}{l}\text { Duration of mechanical } \\
\text { ventilation (d) }\end{array}$ & $7.9(3.7-38.0)$ & $4.9(2.0-31.1)$ & .21 \\
\hline Length of ICU stay (d) & $12(5-96)$ & $8(4-45)$ & .19 \\
\hline Length of hospital stay (d) & $20(10-112)$ & $16(9-78)$ & .14 \\
\hline
\end{tabular}

Data are presented as mean \pm SD. NW-BT, Norwood with modified BlalockTaussig shunt; NW-RVPA, Norwood with right ventricle-pulmonary artery conduit; $P O D$, postoperative day; $\mathrm{Do}_{2}$, oxygen delivery; $\mathrm{Vo}_{2}$, oxygen consumption; $I C U$, intensive care unit. Boldface $P$ values indicate significance.

Measurement of regional cerebral oxygen saturation by near-infrared spectroscopy found no differences in oxygenation between the groups after separation from CPB. As the $\mathrm{rSO}_{2}$ is a measure of tissue (arterial, venous, capillary) hemoglobin oxygen saturation, it is not surprising that the small difference in dissolved oxygen content associated with the higher $\mathrm{PaO}_{2}$ in the NW-BT group from 6 hours after $\mathrm{CPB}$ had no measurable effect on the $\mathrm{rSO}_{2}$ (assuming similar cerebral oxygen consumption). Because the INVOS 5100 uses a weighted average for the arterial/venous ratio for the cerebral circulation of 25:75, the slightly higher arterial oxygen saturation in the NW-BT group may not be large enough to cause a measurable difference by cerebral oximetry. This study supports previous findings that indicators of early postoperative systemic oxygen delivery are equivalent in neonates who have undergone the Norwood procedure with an MBTS versus an RV-PA conduit. ${ }^{25} \mathrm{How}-$ ever, because of the small number of measurements of cardiac index, oxygen delivery, and oxygen consumption, further investigation is warranted.

The higher $\mathrm{rSO}_{2}$ at the end of DHCA in the NW-BT group is most likely explained by the shorter duration of arrest and the more frequent use of RLFP. Analysis of the data by RLFP versus DHCA groups found a higher $\mathrm{rSO}_{2}$ in the RLFP group at the end of the arrest period, but no differences in cerebral oxygenation and perfusion after $\mathrm{CPB}$. Cerebral oxygenation has been shown to decrease after CPB during stage I palliation with an MBTS and use of RLFP, ${ }^{26}$ a finding supported by the results of our study. The same pattern of decreased $\mathrm{rSO}_{2}$ is however also seen in those patients who had DHCA without RLFP, and it implies a similar risk to the cerebral circulation after CPB.
Important limitations of this study are the relatively small number of patients in each surgical group and randomization by triiodothyronine rather than by type of shunt or use of RLFP. As this was a substudy, power calculations for sample size were not done ahead of time. Availability of personnel trained in TCD sonography resulted in neurologic monitoring being performed in 27 of the 38 eligible patients enrolled in the primary study. The small sample size limits the power to detect differences both within and between the groups. This would also explain the lack of a significant difference in recovery after surgery, as has previously been shown in our institution. ${ }^{27}$

In conclusion, this study found that the higher diastolic blood pressure after the Norwood procedure with an RV-PA conduit is not associated with higher CBFVs or $\mathrm{rSO}_{2} \mathrm{~s}$. In highly autoregulated beds such as the cerebral circulation, the Norwood procedure with an RV-PA conduit may offer no particular advantage with respect to cerebral perfusion in the early postoperative period. ${ }^{15}$

We acknowledge Ludmila Kyn for database and statistical programming; research nurses Jodi Elder, RN, and Ellen McGrath, RN, for assistance with data collection; and Donna Donati and Donna Duva for data management.

\section{References}

1. Norwood WI, Lang P, Casteneda AR, Campbell DN. Experience with operations for hypoplastic left heart syndrome. J Thorac Cardiovasc Surg. 1981;82:511-9.

2. Griselli M, McGuirk SP, Stumper O, Clarke AJ, Miller P, Dhillon R, et al. Influence of surgical strategies on outcome after the Norwood procedure. J Thorac Cardiovasc Surg. 2006;131:418-26.

3. Stasik CN, Goldberg CS, Bove EL, Devaney EJ, Ohye RG. Current outcomes and risk factors for the Norwood procedure. $J$ Thorac Cardiovasc Surg. 2006;131:412-7.

4. Bartram U, Grunenfelder J, Van Praagh R. Causes of death after the modified Norwood procedure: a study of 122 postmortem cases. Ann Thorac Surg. 1997;64:1795-802.

5. Sano S, Ishino K, Kawada M, Arai S, Kasahara S, Asai T, et al. Right ventricle-pulmonary artery shunt in first-stage palliation of hypoplastic left heart syndrome. J Thorac Cardiovasc Surg. 2003;126:504-9; discussion 9-10.

6. Maher KO, Pizarro C, Gidding SS, Januszewska K, Malec E, Norwood WI Jr, et al. Hemodynamic profile after the Norwood procedure with right ventricle to pulmonary artery conduit. Circulation. 2003;108: 782-4.

7. Mahle WT, Wernovsky G. Neurodevelopmental outcomes in hypoplastic left heart syndrome. Semin Thorac Cardiovasc Surg Pediatr Card Surg Аnпu. 2004;7:39-47.

8. Dent CL, Spaeth JP, Jones BV, Schwartz SM, Glauser TA, Hallinan B, et al. Brain magnetic resonance imaging abnormalities after the Norwood procedure using regional cerebral perfusion. $J$ Thorac Cardiovasc Surg. 2006;131:190-7.

9. Galli KK, Zimmerman RA, Jarvik GP, Wernovsky G, Kuypers MK, Clancy RR, et al. Periventricular leukomalacia is common after neonatal cardiac surgery. J Thorac Cardiovasc Surg. 2004;127:692704.

10. Mackie AS, Booth KL, Newburger JW, Gauvreau K, Huang SA, Laussen PC, et al. A randomized, double-blind, placebo-controlled pilot trial of triiodothyronine in neonatal heart surgery. $J$ Thorac Cardiovasc Surg. 2005;130:810-6.

11. Bode H. Pediatric applications of transcranial Doppler sonography. Wien: Springer-Verlag; 1988. 
12. Watzman HM, Kurth CD, Montenegro LM, Rome J, Steven JM, Nicolson SC. Arterial and venous contributions to near-infrared cerebral oximetry. Anesthesiology. 2000;93:947-53.

13. Kurth CD, Steven JL, Montenegro LM, Watzman HM, Gaynor JW, Spray TL, et al. Cerebral oxygen saturation before congenital heart surgery. Ann Thorac Surg. 2001;72:187-92.

14. van der Linden J, Priddy R, Ekroth R, Lincoln C, Pugsley W, Scallan $\mathrm{M}$, et al. Cerebral perfusion and metabolism during profound hypothermia in children: a study of middle cerebral artery ultrasonic variables and cerebral extraction of oxygen. J Thorac Cardiovasc Surg. 1991;102:103-14.

15. Buijs J, Van Bel F, Nandorff A, Hardjowijono R, Stijnen T, Ottenkamp J. Cerebral blood flow pattern and autoregulation during openheart surgery in infants and young children: a transcranial, Doppler ultrasound study. Crit Care Med. 1992;20:771-7.

16. Halsey JH, McDowell HA, Gelman S. Transcranial Doppler and rCBF compared in carotid endarterectomy. Stroke. 1986;17:1206-8.

17. Aaslid R, Markwalder TM, Nornes H. Noninvasive transcranial Doppler ultrasound recording of flow velocity in basal cerebral arteries. J Neurosurg. 1982;57:769-74.

18. Demolis P, Chalon S, Giudicelli JF. Repeatability of transcranial Doppler measurements of arterial blood flow velocities in healthy subjects. Clin Sci (Lond). 1993;84:599-604.

19. Kontos HA. Validity of cerebral arterial blood flow calculations from velocity measurements. Stroke. 1989;20:1-3.

20. Greeley WJ, Bracey VA, Ungerleider RM, Greibel JA, Kern FH, Boyd $\mathrm{JL}$, et al. Recovery of cerebral metabolism and mitochondrial oxidation state is delayed after hypothermic circulatory arrest. Circulation. 1991;84(Suppl):III400-6.
21. O'Hare B, Bissonnette B, Bohn D, Cox P, Williams W. Persistent low cerebral blood flow velocity following profound hypothermic circulatory arrest in infants. Can J Anaesth. 1995;42:964-71.

22. Astudillo R, van der Linden J, Ekroth R, Wesslen O, Hallhagen S, Scallan M, et al. Absent diastolic cerebral blood flow velocity after circulatory arrest but not after low flow in infants. Ann Thorac Surg. 1993;56:515-9.

23. Bassan H, Gauvreau K, Newburger JW, Tsuji M, Limperopoulos C, Soul JS, et al. Identification of pressure passive cerebral perfusion and its mediators after infant cardiac surgery. Pediatr Res. 2005;57:35-41.

24. Adams RJ, Nichols FT, Hess DC. Normal values and physiological variables. In: Newell DW, Aaslid R, editors. Transcranial Doppler. New York: Raven Press; 1992. p. 41-8.

25. Bradley SM, Simsic JM, McQuinn TC, Habib DM, Shirali GS, Atz AM. Hemodynamic status after the Norwood procedure: a comparison of right ventricle-to-pulmonary artery connection versus modified Blalock-Taussig shunt. Ann Thorac Surg. 2004;78:933-41; discussion -41 .

26. Hoffman GM, Stuth EA, Jaquiss RD, Vanderwal PL, Staudt SR, Troshynski TJ, et al. Changes in cerebral and somatic oxygenation during stage 1 palliation of hypoplastic left heart syndrome using continuous regional cerebral perfusion. J Thorac Cardiovasc Surg. 2004;127:223-33.

27. Cua CL, Thiagarajan RR, Gauvreau K, Lai L, Costello JM, Wessel $\mathrm{DL}$, et al. Early postoperative outcomes in a series of infants with hypoplastic left heart syndrome undergoing stage I palliation operation with either modified Blalock-Taussig shunt or right ventricle to pulmonary artery conduit. Pediatr Crit Care Med. 2006;7:1-7. 